\title{
Working Capital Management in Government Technical Training Institutions in Kenya
}

\author{
Kung'u, J. N., Njui, N. W., Kimani, L. W. \\ Department of Business, Nyandarua Institute of Science \& Technology \\ Department of Business, Nyandarua Institute of Science \& Technology \\ Department of Business, Kabete Technical Training Institute
}

\begin{abstract}
Technical training in a country plays a strategic role in providing highly skilled artisans, craftsmen, technicians and technologists with the expectation of bringing about economic growth. The study looked at the working capital approaches used by the government technical training institutions in managing their current assets and current liabilities. All the 42 government technical training institutions were taken and the Principals were the respondents. Data was collected by use of questionnaires and were received. The data was analysed using descriptive statistics; graphs charts, percentages, means and standard deviations. The findings of this study suggest that the management of working capital components in government technical training institutions is moderate. The study has identified the factors that influence working capital management, and has also established the extent of application of finance techniques and models in these institutions. The management of working capital in these institutions must not be left to intuition or the rule of the thumb. It should be improved, by having written policies on each of the working capital components, by application of techniques and models which include planning, controlling and monitoring of current assets and current liabilities in order to achieve liquidity. Computerization of key departments will enhance operating and financial efficiencies considering that working capital management depends on quantitative data which must be accurate and timely for proper decision making. The government should continue assisting these public institutions, whose products will be instrumental in achieving the Kenya Vision 2030.
\end{abstract}

Key Words: (Technical Training Institutions, TVET, Working Capital)

\section{Introduction}

Technical education in Kenya dates back to 1924 when the colonial government opened a Native Industrial Training Depot at Kabete. The training courses offered were mainly directed towards the building trades. As Kenya's industrial sector expanded, there was need to formalize industrial training policy hence the Industrial Training Ordinance was enacted in 1959 to enforce training in the country. Immediately after independence in 1963, Kenya was faced with acute shortage of manpower. The Ominde Commission which was set up which recommended that technical and trade schools be developed to become technical secondary schools to produce graduates who would be academically competent and basically skilled enough to advance quickly in the labour market. By 1973, technical schools were located in Thika, Nakuru, Mombasa, Sigalagala, Kaiboi Machakos, Mawego, Meru and Kisumu which offered pre-craft training in masonry, carpentry and allied trades (D'souza, 1976). Currently there are two (2) polytechnic universities, two (2) national polytechnics, one (I) technical teachers college, twenty (20) Technical Training Institutes (TTIs) and seventeen (17) Institutes of Technology which are TIVET institutions under Ministry of Higher Education, Science and Technology (R.O.K, 2013). One of the foundations of Kenya Vision 2030 is the application of science, technology and innovation in order to intensify and raise production and efficiency levels across the pillars of economic, social and political governance. Kenya Vision 2030 also addresses transparency and accountability in that government institution should be transparent, accountable, ethical and results oriented.

Dell Computer, a company in the United States, in the computer industry was rated by Fortune one of the most successful company with its sales growing from around $\$ 5$ billion in 1995 to $\$ 36$ billion in 2003 . Dell's remarkable performance was due to impressive success in managing working capital components as well as the use of information technology in its operations (Brigham and Ehrhardt, 2004). The lessons taught by Dell Computer extended to other industries. According to Brigham and Ehrhardt (2004) the ideas of improving working capital management often stems from other disciplines, for example experts in logistics, operations management, information technology and marketing. Finance comes into play in evaluating profitability of alternative proposals. According to Levy and Sarnat (1988) "Nothing is more permanent than the temporary" in that if a company is to operate efficiently, working capital must be tightly monitored and controlled. The management of working capital is usually a direct responsibility of a finance manager and this requires day to day supervision. 
Decisions on how to finance current assets involve trade off between risk and profitability. The greater the relative proportion of liquid assets, the less the risk of running out of cash, but profitability unfortunately, will be less. Effective management of various components of current assets, effective credit and collection procedures and inventory control have a bearing on the liquidity of the firm (Van Horne, 1989). The resolution of trade off between risk and profitability with respect to the decision depend on the risk preference of the management, who, it is hoped, have an eye on the likely impact of a decision on the firm's valuation. All firms require working capital, only differing in composition of the components and the controls and policies implemented. There is no universally accepted strategy for financing working capital; however there are principles that address short term financing policies (Levy and Sarnat, 1988).

Different firms approach the problem of working capital differently. Typically, management relies on use of ratio analysis and similar rules of the thumb, to determine the efficiency in which short term resources are allocated. The advent of computer, and the increasing use of financial models, has allowed firms to apply more formal methods to gauge the effectiveness of their working capital strategy. Working capital management tries to provide easily implementable rules for routine decision making as well as a framework for continuous monitoring and evaluation of policy guidelines. Effectiveness in working capital management implies closely related types of action. First, policies must be set regarding the desired level of each asset component' Second, an administrative framework for management and controlling these assets within the policy guidelines and thirdly financing of the investment in current assets (Levy and Sarnat, 1988).

The management of working capital entails management of inventories, accounts receivables, accounts payables and cash. These are necessary components in the day to day running of technical training institutions in Kenya. Technical training institutions are expected to play a strategic role in providing high quality skilled personnel for both the formal and informal sector. Free primary education will ultimately result in secondary school leavers applying to join these institutions. The challenges facing technical training institutions in Kenya include; inadequate facilities, mismanagement of scarce resources, wastefulness and unnecessary competition. Many heads of institutions lack capacity to oversee and account for utilization of resources.

Although these institutions are partly funded by the government in recurrent expenditure, it is important to find out the working capital management practices used in order to determine the level and composition of their current assets, the sources to finance current assets, and the measures taken to ensure sound liquidity is maintained. The study has been selected because no research has been carried out in this area of working capital management. These public institutions are operating in a competitive environment of established and upcoming private training institutions, which are in business and employ qualified finance officers who are responsible for ensuring the liquidity, profitability and solvency of the businesses.

The recent TVET reforms outlined in Education Sector Report (2008) indicates improved funding of technical training institutions and a move to instil good governance, accountability and transparency in handling public funds. The study seeks to find out if these institutions are maintaining sustainable and optimal levels of working capital components by making use of policies, planning and control techniques and whether the management of working capital is enhanced by hiring of qualified personnel. The study was guided by four research questions;

i) What is the composition of working capital components found in technical training institutions?

ii) Which are the approaches used in management of working capital components in institutions?

iii) What are the factors that influence the management of working capital in institutions?

iv) Which finance models and techniques are applied by technical institutions in the management of work capital?

\section{Literature Review}

There are two concepts of working capital, gross and net working capital (Pandey, 2008). Gross working capital refers to a firm's investment in current assets. Current assets are assets which can be converted into cash within an accounting year, and include cash, short term securities, accounts receivables, bills receivables and inventory. Net working capital refers to the difference between current assets and current liabilities. Current liabilities are those claims of outsiders which are expected to mature within an accounting year and include accounts payable, bills payable and outstanding expenses (Pandey, 2008). He states that net working capital is a qualitative concept, indicating the liquidity position of a firm.

Pandey (2008) states that two aims of working capital management are profitability and solvency. Thus, a liquid firm has less risk of insolvency. However, there are costs associated with sound liquidity in that 
funds will be held up in current assets and the firm's profitability will suffer. McLaney (2000) argue that one way to avoid the risk of liquidity is to maintain large amounts of cash on short term interest bearing deposits. In this way cash can be made available quickly to meet demand. Most business failures result from a deficiency in working capital.

An example of matching approach is that stock of goods to be sold in 30 days may be financed with a 30 day commercial paper. A conservative approach is one which depends more on long term funds for financing needs, and hence the firm has less risk of facing the problem of shortage of funds. Aggressive approach is when the firm uses more short term financing than warranted by the matching plan. The firm finances part of permanent current assets with short term financing making the firm more risky. While short term financing may be preferred over long term financing because of the cost advantage and flexibility, it is more risky than long term. The choice between long term and short term financing involves a trade off between risk and return.

Pandey (2008) outlined some major determinants of working capital. The nature of the business whether manufacturing or service rendering; the market demand conditions in that working capital needs are related to sales which depends on demand conditions; technology and manufacturing process in that the longer the manufacturing cycle, the larger the firms working capital requirement; credit policy of a firm which affects the working capital by influencing the level of debtors; availability of credit suppliers in that a firm offering liberal credit terms will need less working capital and absence of supplier credit will require the firm to borrow from the bank; operating efficiency in that optimum utilization of all resources of a firm reduces costs and also accelerates the cash conversion cycle; and finally price level changes affect working capital requirement in that a rise in prices means a higher amount of working capital.

The level of inventory varies greatly among the firms. For firms with large inventories a drop of $1 \%$ in inventory can save the firm over a million dollars in interest costs alone (Levy and Sarnat, 1998). Training institutions will hold stocks in form of stationery, food stuff (boarding), teaching materials and consumable stores which generally vary with student enrolment. Firms attempt to minimize the cost of holding inventory because inventory decisions are repetitive, the relevant management decision often relate to 'how often' and 'how much' inventories should be replenished. The requirements for inventory vary with activity and time of the year. According to McLaney (2000) firms should seek to balance the cost of holding stock with those of holding no (or low) levels of stock. While the costs of holding stocks are loss of interest, storage and insurance costs, obsolescence, it is difficult to identify the costs of failing to hold stock because they may not occur (risk) hence their costs are in the nature of expected values i.e. the cost combined with the probability of occurrence. The cost of holding no (or low) stocks include loss of customer goodwill, production dislocation, loss of flexibility which lead to 'hand to mouth existence' such that even a slight increase in sales demand (or consumption) the firm will be unable to meet the demand (McLaney, 2000). Reorder costs also increase as a firm is forced to place a large number of small orders at short notice because the firm is operating at danger level of stocks (Din, 1984).

While overstocking may lead to deterioration of quality of some stock items especially consumables, the stock item of foodstuffs in training institutions has been sensitive usually due to quantity or quality. Din (1984) asserts that in inventory management there should be the right quantity of the right quality at the right price from a right supplier and at the right time. Institutions should determine the economic order quantity so that they can minimize ordering and storage costs. They establish optimal order quantities for each stock item and these quantities should be periodically revised. Stock reorder levels should be established which largely depends on the lead time. Most computer packages dealing with stock records have a facility for incorporating reorder levels for each stock item so that the computer output will draw attention to the need to place the next order (McLaney, 2000)

The importance of forward planning and budgeting is crucial for inventory management and it concerns knowing what to expect in terms of levels of demand. It is rarely possible in practice to gain sufficient information on stocks from physical observations hence reliable stock records are essential for inventory management. There should be established stock checking procedures. ABC classification method is where stocks are classified into categories of importance so that a firm can apply the most elaborate procedure of controlling stock to the most important items (Drury, 2004). Modern techniques like JIT of stocks and production control can be established where there is a close relationship between users and suppliers obviating the necessity of buffer stocks which brings about stockholding savings (McLaney, 2000). 
Firms hold stocks for three general reasons; the transaction motive which is the need to hold stocks to meet production and sales requirement, precautionary motive which is the holding of additional stocks when the future demand is uncertain, and speculate motive when it is expected that future input prices may change. A firm may maintain higher or lower stock levels to speculate on the expected increase or decrease (Drury, 2004). Din (1984) argues that misappropriation of inventory is simpler than cash and any theft, waste and excessive use of materials are immediate direct and indirect financial losses. Proper security and authorization relating to stock should be established.

Selling in cash is ideal. However, selling on credit is inevitable. Brigham and Ehrdart (2004) state that firms would in general, rather sell for cash than on credit; but competitive pressures force most firms to offer credit. They noted that receivables management begins with credit policy, but a monitoring system is also important. When a credit sale is made, inventories are reduced, accounts receivables are increased the difference being profit. They state that firms have been known to encourage 'sales' to very weak customers in order to report high profits. Similarly government training institutions are obliged to admit potentially uncreditworthy students raising the student population which increases accounts receivable rather than cash. Ngaba (1990) carried out a study on working capital management in secondary schools. He found that the government discourages the act of expelling students for lack of fees since every Kenyan is entitled to the right of education. The same tendency of leniency applies in post secondary government institutions and part payments are acceptable.

Institutions should establish credit policies for the establishment of effective administration of debtors. Most computer packages can produce a list of debtors showing the length of time for which a debt has been outstanding and similar devices which can be usefully employed by finance officers in pursuit of debts. A policy on bad debts should be followed except in unusual circumstances. The writing of the debt should be authorized by a responsible senior employee (McLaney, 2000). To estimate the probability of default, the finance officer should consider the character-willingness to pay, the capacity - customers financial position, and condition economic or any other which may affect the customer's ability (Pandey, 2008). In secondary schools, the principal is the one who is responsible for ensuring that overdue debts are cleared (Ngaba, 1990). Though collection procedures should be firmly established, individual cases should be dealt with on their own merits.

Cash is the most important current asset for the operations of a business and it is the basic input needed to keep the business running on a continual basis (Pandey, 2008). The term cash includes coins, currency and cheques held by a firm and balances in its bank. Sometimes near cash items such as marketable securities or bank short deposits are also included in cash. Mclaney (2000) noted that some firms may not hold stock; others may have no trade debtors or creditors because they neither receive nor give credit but all of the firms have cash or negative cash balances. The aim of cash management is to maintain effective control over the cash position and to keep a firm so sufficiently liquid and to use excess cash in some profitable way. Some technical institutions have put in place income generating activities which are still weak and require to be strengthened. The levels of recurrent funding are still low, hence need for strategies for enhancing resource base for efficient and effective implementation of TIVET programmes.

Cash management is concerned with the managing of cash flows into and out of the firm (Pandey, 2008). Cash management seeks to accomplish the cash cycle at a minimum cost. At the same time it also seeks to achieve liquidity and control. Firms hold cash for transaction motives to conducting its business in the ordinary course; precautionary motive to provide a buffer to withstand some unexpected emergency; speculative motive for investing in profit making opportunities as and when they arise (Pandey, 2008). If a bank is providing services to a customer, the firm may also be required to hold cash called compensating balances according to (Brigham and Ehrhardt, 2004).

A firm should establish policies for cash and plan cash flows, through budgets, make judicious use of bank overdraft and deposit accounts, bank cheques and cash frequently and time transactions to the best cash flow effects. An attempt to accelerate collections and slow up disbursement should be made so that maximum cash is available. Training institutions currently receive payments by students using deposit slips showing amounts banked in the institution account. This is not only for security reasons of handling cash but it is a direct banking to the organization which is usually before admission of the students. The cost of holding cash includes loss of interest and purchasing power and cost of holding little or no cash includes loss of supplier goodwill, loss of opportunities, inability to claim discounts and cost of borrowing (McLaney, 2000). The Baumol's cash model is similar to the inventory management model since cash and inventory problems are similar. This model assumes that the firm's cash balance takes a saw tooth pattern over time and that receipts come at intervals while 
expenditure occurs continuously. In general government training institutions operating at full or near full capacity will have receipts at intervals and expenditure continuous.

Obulemire (2006) survey on budgeting in secondary schools noted that the size in terms of student population had no effect on the occurrence of deficit or surplus in the school operations. He noted that the number of students in schools was mostly considered as the key budget factor and most schools did not have a strategic plan to guide them towards achievement of both short and long term objectives. He found that the finance officers were not qualified to hold their positions in schools because they lacked knowledge concerning idle funds, cost and cash balances.

Mulera (2005) carried out a study on cash balances on public universities in Kenya. He found that public universities in Kenya face a challenge of financing their operations due to reduced government grant causing delay in payment of recurrent expenditures.

Ngaba (1990) study on working capital management in secondary schools noted that the principal was responsible for establishing procedures for collecting overdue debts. No attempt was made to evaluate the credit worthiness of a student. In some cases the parent was called to commit himself or herself to pay fees balances by a stated date. Sometimes exam results were withheld for non payment of fees balances, but it was noted that some students would not come for results slips for O-level exams even afterwards. He noted that fees were the major cash inflow and recommended the heads of schools to be trained in financial management.

\section{Methodology}

A descriptive research design approach was used. The research study took a census simply because the number of technical institutions in Kenya was few. The target population was 42 principals of technical training institutions in Kenya. A self-administered structured questionnaire was used to collect primary data and 34 questionnaires were filled in and returned. This was $81 \%$ response rate. Analysis was done through the use of SPSS version 20.0 and presentation was done using mean, standard deviations, frequency tables and graphs.

\section{Results and Discussion}

The respondents indicated that most of the institutions had written policies. Majority of the institutions had written policy on cash and bank (88\%) followed by accounts payable $(85 \%)$, accounts receivable $(79 \%)$ and inventories $(65 \%)$ respectively.

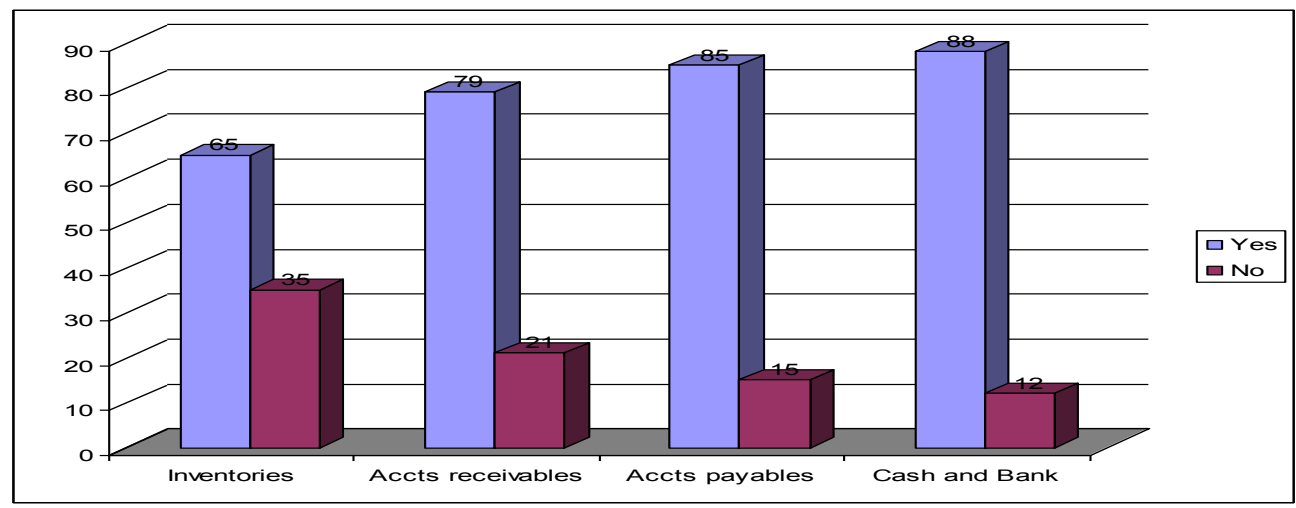

Figure 1: Existence of a Written Policy

The individual currents assets were ranked by the respondents according to amounts held from the largest to the least. The respondents ranked inventories with a mean of 1.5714 with a standard deviation of 0.79015 as the item constituting the largest amount of the institutions current assets, followed by debtors-fees mean (2.500), bank/cash balances mean (2.7333) and investments mean (2.9310).

Table 1: Ranking of Current Assets

\begin{tabular}{lcc}
\hline & Mean & Std. Deviation \\
\hline Inventory & 1.5714 & .79015 \\
Debtors fees & 2.50 & 1.075 \\
Investments & 2.9310 & 1.09971 \\
Bank/cash balances & 2.7333 & .94443 \\
\hline
\end{tabular}


The findings from the study revealed that inventory was ranked as the largest amount mean (1.5714) of institutions current asset components. This could be attributed to the fact that most institutions are boarding (91\%). Stocks of food and fuel accounted for the largest cost of item held in stock mean (2.0303) followed by practical materials mean (2.0909), stationery mean (2.5455) and consumable stores mean (3.333) having the least cost. $47 \%$ of the institutions indicated that they had established inventory levels. However, most respondents did not specify how the levels were determined. A few respondents explained that the levels were determined by past trends in inventories, while others generally explained that the inventory level depended on the level of the demand. Availability of written policies on inventory was ranked the lowest $(35 \%$ of the institutions had no written policies on inventory) compared to written policies on other current assets. Furthermore the findings revealed that inventory budget was not stated under any other budget prepared by the institutions.

The findings revealed that $85 \%$ of the institutions had written policies on accounts payables. However no institution indicated preparation of accounts payable (creditors) budget. This may imply that only the cash budget captures the payments of accounts payables. The findings indicated that payments for goods and expenses were made basically on termly or monthly basis. The respondents rated punctual deliveries by suppliers as average (mean 2.3333). Prompt payment to suppliers (mean 1.6667) and prompt payment of workers salaries (mean 1.5152) was rated as good. Other findings on payments of suppliers promptly indicated that $15 \%$ of the institutions did not pay suppliers promptly to earn cash discounts, $56 \%$ paid promptly sometimes and only $29 \%$ always paid promptly. This finding suggests that there may be subjectivity in the manner accounts payable are handled by various institutions.

Computerization process has been done at various levels in various departments of the institutions. The highest level has been achieved in accounts/finance department (64\%) and registry/deans (55\%) due to the nature of the duties these two departments are involved in on day to day basis. Stores department have only achieved $21 \%$ computerization level. At the same time some institutions (31\%) have none of the departments above computerized. Working capital management is a discipline that requires financial records in order to analyse and apply techniques which are computer oriented, for proper planning, control and monitoring of working capital components, and the general operations of the institutions.

Table 2: Computerized Areas

\begin{tabular}{lcc}
\hline & Frequency & Percentage \\
\hline Stores departments & 7 & 21 \\
Accounts/finance department & 21 & 64 \\
Registry /deans & 18 & 55 \\
None & 10 & 31 \\
\hline
\end{tabular}

The credit policy affects working capital by influencing the level of debtors. Assessment of creditworthiness of students in government training institutions is rarely practiced, which was the greatest factor (79\%) that affected debt collection, followed by government policy $15 \%$ and lastly credit control which was $6 \%$. The findings also revealed that accounts receivables relating to fees were the second largest current asset component. Inefficient credit policy leads to large accounts receivables and less liquidity, affecting working capital.

Table 3: Influence of Debtors Level by Credit Policy

\begin{tabular}{lcc}
\hline Factor & Frequency & Percentage \\
\hline Creditworthiness Assessment & 27 & 79 \\
Government Policy & 5 & 15 \\
Credit Control & 2 & 6 \\
Total & 34 & 100 \\
\hline
\end{tabular}

Operating efficiencies leads to optimal utilization of working capital resources of a firm. Written policies relating to working capital components improve efficiency. Proper and up to date recording of the working capital components requires adequate and competent staff who can prepare reports to management for planning and decision making. The findings revealed that a total of 66 accounting staff had Accounting Technicians Certificate, CPA Part I and Diploma qualifications, 36 had CPA Part II and III and only 5 had bachelor or masters degree qualification. This suggests that compared to private firms qualifications are low for the staff yet some are handling financial matters of large institutions. Preparation of all functional and master budgets enables an organization to chart its way forward and also to identify areas that need attention in advance. Most institutions indicated that they prepared only Cash Budgets and Budgeted financial statements. 
Table 4: Accounting Staff Level of Education

\begin{tabular}{lcc}
\hline Academic Level & Frequency & Percentage \\
\hline Accounting Technician Level & 30 & 28 \\
Diploma Level & 6 & 6 \\
Certified Public Accountant Part 1 & 30 & 28 \\
Certified Public Accountant Part 11 \& 111 & 36 & 34 \\
Bachelor and Masters Degree Qualification & 5 & 5 \\
Total & 107 & 100 \\
\hline
\end{tabular}

The cash receipts and payment pattern affect the working capital requirement of institutions. If not properly synchronized, the institutions can experience cash deficits which will affect their operations. The respondents also indicated that the fees structure was inadequate to cope up with the high cost of food related items and that affected the liquidity of the institutions. The rising prices means that higher amount of working capital will be needed.

The respondents indicated that their institutions do not utilize bank overdrafts, short term loans or long term bank loans in financing their current assets. This could mean that the government assists in financing or the use of the financing is outside government policy for the institutions. The findings revealed that financing through accounts payables in form of goods (mean 1.6071) and services (mean 1.7857) was practiced. This suggests that the institutions are rated as creditworthy government institutions; hence require minimum or no cash financing to obtain goods and services.

Table 5: Usage of Liabilities

\begin{tabular}{lcc}
\hline & Mean & Std. Deviation \\
\hline Bank Overdraft & 2.8519 & .36201 \\
Creditors Goods & 1.6071 & .56695 \\
Creditors Service & 1.7857 & .56811 \\
Short Term Loans & 2.8462 & .36795 \\
Bank Long Terms Loans & 2.8077 & .40192 \\
\hline
\end{tabular}

\subsection{Technology}

Forty two percent of the institutions prepared Cash Budgets and 58\% prepared Budgeted financial statements. No respondent indicated that their institutions prepared other operating budgets. This shows that all the institutions do normally prepare budgets. Preparation of budgets is a planning as well as a control technique. The schools prepare budgets to enable them plan for the following financial year. Government technical training institutions prepare budgets their financial years that either start on $1^{\text {st }}$ July or $1^{\text {st }}$ January each year. The budgets are presented to the finance committees for scrutiny before presented to the board of management for approval.

Table 6: Preparation of Budget

\begin{tabular}{lcc}
\hline Type of Budget Prepared & Frequency & Percent \\
\hline Cash Budget & 14 & 42 \\
Budgeted Financial Statements & 20 & 58 \\
Other Budgets & 0 & 0 \\
Total & 34 & 100 \\
\hline
\end{tabular}

A significant Majority of the respondents (85\%) indicated that their institutions have profit generating activities and only $15 \%$ indicated that they do not have. This indicates that the institutions do not solely depend on the school fees paid by the students. Government technical institutions have large pieces of land especially the institutes of technology. They practice agriculture where they consume the products from the farm and sell surplus. They have developed production units with the institutions. They produce for the local market. This is a major source of revenue for such institutions.

Table 7: Existence of Profit Generating Activities

\begin{tabular}{lcc}
\hline & Frequency & Percentage \\
\hline Yes & 29 & 85 \\
No & 5 & 15 \\
Total & 34 & 100 \\
\hline
\end{tabular}


The policy of the institutions is that the students should clear paying their fees before the end of the term. Students are not allowed to sit for end of terms examination before clearing the fees. The end term examinations are send to Kenya National Examination Council and counts to the final examination. A majority $56 \%$ of institutions use the policy of clearing the unpaid fees balance before term ends/semester exam, $32 \%$ requires that the unpaid balance be cleared before beginning of new term. Other three durations comprising of $12 \%$ are not popularly amongst all the institutions. Notable was that candidates were required to clear fees before registration for examinations. The institutions do not assess the creditworthiness of their students.

Table 8: Mode of Fees Payments in the Institutions

\begin{tabular}{lcc}
\hline & Frequency & Percent \\
\hline Cash & 1 & 3 \\
Bankers cheques & 4 & 12 \\
Money orders & 0 & 0 \\
Personal cheques & 0 & 0 \\
Direct deposits & 34 & 100 \\
\hline
\end{tabular}

Educational institutions hold cash because of the day today running of their institutions. In response to the question on the reasons why they hold cash and whether they experience cash deficits and surpluses, the respondents indicated that they neither experience cash surplus nor deficits. A majority $82 \%$ hold cash to avoid running out of cash in case of emergency while non of the institutions hold cash for profit making opportunities.

Table 9: Reason for Holding Cash

\begin{tabular}{lcc}
\hline & Frequency & Percentage \\
\hline Running the day to day transactions & 34 & 100 \\
Avoiding running out of cash in case of emergency & 28 & 82 \\
In case profit making opportunities arises & 0 & 0 \\
\hline
\end{tabular}

Institutions in Kenya in the past experienced a lot burglary and lost a lot of money. Burglary sometimes results in death especially of the security officers on duty. Better methods of receiving cash from students have iced by schools. Direct deposit and bankers cheques are have been adopted by the institutions under the study.

Table 10: Duration of Clearing Unpaid Balances

\begin{tabular}{lccc}
\hline & Frequency & Percent & Cumulative Percent \\
\hline After one month & 2 & 6 & 6 \\
After one week & 1 & 3 & 9 \\
As and when students are able & 1 & 3 & 12 \\
Before beginning of new term & 11 & 32 & 44 \\
Before term ends/semester exam & 19 & 56 & 100 \\
Total & 34 & 100 & \\
\hline
\end{tabular}

\section{Conclusions}

The findings of the study concluded that the management of working capital is moderately applied in government technical training institutions. Even though each component has some form of control, the findings revealed that there is greater inefficiencies in management of the accounts receivables in form of fees compared to management of inventory, cash or accounts payables. Planning aspect for the working capital components is not adequate except the cash component. Inadequate working capital planning will manifest itself in operating inefficiencies. The use of technology is moderate in these institutions. Ideally, all key departments should be computerized. The findings indicated that some institutions have not computerized any of the key departments. Efficiency in working capital management of these institutions will largely depend on quantitative data which must be accurate and timely in order to aid in proper decision making. Furthermore, the use of financial models and techniques is easily done by computer.

\section{Recommendations}

Working capital management in technical institutions should not be left to intuition or the rule of the thumb. Each working capital component should not only have written policies, but such policies should be strictly followed and reviewed where necessary to incorporate the changing trends. Proper management of 
working capital should bring about improved operating efficiencies. This may be achieved by adequate records relating to each working component, proper planning of cash flows to improve liquidity and maintaining of optimal levels of each working capital component. Institutions should ensure that all key departments are computerized and employment of qualified accounts staff who will generate reports to management for decision making related to current assets and current liabilities. With computerization a full budgetary control system could be adopted which will include, inventory, accounts payables and receivables and cash budget. Inventory and cash control techniques could also be applied in a computerized environment. Credit control procedures for fees payment, suitable for these training institutions should be adopted.

\section{Suggestions for Further Research}

The study recommends a comparative study on working capital management in private training institutions. They are profit oriented institutions and working capital management is essential for such organizations in order to achieve liquidity, profitability and solvency.

\section{Reference}

[1]. Amoro, Y. (1991). Inventory Optimization. Determining Major Inventory Parameters into the case of Hosps at KBL, Nairobi University

[2]. Atchoarenu, D. (1993). Policy and Planning for Vocational Training; Report of a sub-regional training workshop, UNESCO. International Institute for Education and Planning, Barbados.

[3]. Brigham, E. F. \& Ehrhardt, M. C. (2004), Financial Management Theory and Practice, $11^{\text {th }}$ Edition, Elm street Publishing Services, Ohio.

[4]. Din, N.U. (1984). Cost Accounting and Budgeting Made Simple. Nairobi: Standard Accounting Publication Co.

[5]. Drury, C. (2004). Management and Cost Accounting, $6^{\text {th }}$ Edition. London: Thompson Learning

[6]. D'souza, H. (1976). Technical Education in Kenya, Africa Studies Review, Vol. 19, No 3, pp 33-41

[7]. Education Sector Report (2008) Realizing Vision 2030 Goals through effective and efficient Public Spending, Republic of Kenya, MOHEST.

[8]. Financial Management Manual (2007) for Ministry of Science and Technology Headquarters, Field Officers, SAGA and TIVET institutions. Republic of Kenya, MOHEST

[9]. Godfrey E. M. (1973) TVT in Kenya HITs Discussion paper No. 169, Nairobi

[10]. HITS Kenya Mission (1984) Project Funding and Recommendation Report, Nairobi.

[11]. Kenya Vision 2030 A Global Perspective and Competition Kenya, Republic of Kenya

[12]. Levy, H. \& Sarnat, M. (1988). Principles of Financial Management. London Prentice-Hall International

[13]. Lucey T (1998), Costing, $5^{\text {th }}$ Edition. London: DP Publications,

[14]. Lumbasyo, L. O. (1976). Cash balance Management. Nairobi: University of Nairobi Press

[15]. Manas'seh, P. N. (1991). Business Finance. Nairobi: Mc More Accounting Books

[16]. McLonely, E. J. (2000). Business Finance Theory and Practice, $4^{\text {th }}$ Ed. London: Financial Times Pitman Publishing

[17]. McMennamin, J. (1999). Financial Management: An Introduction. London: Routledge Publishers.

[18]. Mugenda, O. M. \& Mugenda, A. G. (1999). Research Methods, Quantitative and Qualitative Approaches.Nairobi: African Centre for Technology Studies Press

[19]. Mugera (1998). Cash Management Practices in Small Business Enterprises, U S I U Africa

[20]. Mulera, E. (2005). An Investigation of Cash Balance Management in Public Universities, Kenyatta University.

[21]. Ngaba, D. K. (1990). Working Capital Management Practices in Kenya Secondary Schools: Kikuyu Division, Kiambu District, Nairobi University

[22]. Obulemire T A (2006), A Survey of Budgeting Practices in Secondary Schools in Nairobi. Nairobi: University of Nairobi Press

[23]. Okaka, P. O. (1995). Promoting and Improving Cooperation between Technical Training Institutions and Industries in Kenya, UNESCO Assisted Pilot Project Report.

[24]. Okumbe, L. (1998). Education Management Theory and Practice. Nairobi: University of Nairobi Press

[25]. Pandey, I. M. (2004). Financial Management, $9^{\text {th }}$ Edition. New Delhi: Vikas Publishing House

[26]. R. O. K. (2005). Sessional Paper Nol of 2005, Policy Framework for Education Training and Research, Meeting the challenges of Education, Training and Research in Kenya in the $21^{\text {st }}$ century. Nairobi: Government Printers

[27]. R. O. K. (2007). TIVET Investment in Infrastructure, Centre of Excellence Industrial Incubators and TIVET Bursaries. Nairobi: Government Printers

[28]. VanHorne J. C. (1989). Fundamentals of Financial Management, $7^{\text {th }}$ Edition. New Jersey: Prentice Hall 